
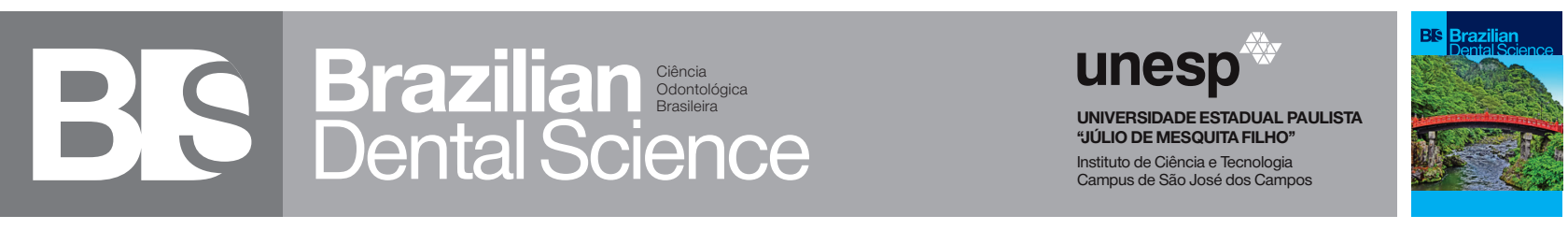

\title{
Edemogenic test and hydrogen peroxide degradation rate of bleaching gels with different desensitizing agents
}

Teste edemogênico e taxa de degradação do peróxido de hidrogênio de géis clareadores com diferentes agentes dessensibilizantes

André Luiz Fraga BRISO ${ }^{1}$, Marjorie Oliveira GALLINARI ${ }^{1}$, Francine BENETTI', Diego VALENTIM ${ }^{1}$, Carlos Roberto Emerenciano BUENO $^{1}$, Fabiano Carlos MARSON ${ }^{2}$, Eloi DEZAN JUNIOR ${ }^{1}$, Luciano Tavares Ângelo CINTRA ${ }^{1}$

1 - Department of Restorative Dentistry - Araçatuba Dental School - UNESP - Univ Estadual Paulista - Araçatuba - SP - Brazil.

2 - Dental Press Ensino e Pesquisa Ltda - Maringa - PR - Brazil.

\section{ABSTRACT}

Objective: The at-home bleaching technique leads to the intimate contact of the bleaching gel with gingival tissues, so this study evaluated the immediate inflammatory response, through the edemogenic test, induced by at-home bleaching gels of $10 \%$ carbamide peroxide with different desensitizing agents, the quantification of hydrogen peroxide released and bleaching gels $\mathrm{pH}$. Material and Methods: Forty-eight rats were divided into groups $(\mathrm{n}=12)$ : $\mathrm{CTRL}$-control group, WP-Whiteness Perfect 10\% (FGM Produtos Odontológicos, Joinville, SC, Brazil), OPA-Opalescence $10 \%$ (Ultradent Products Inc., South Jordan, IT, USA), and PB-Power Bleaching (BM4, Palhoça, SC, Brazil). For the edemogenic test, all rats received an intravenous injection of Evan's Blue; after $30 \mathrm{~min}$, $0.2 \mathrm{~mL}$ of each bleaching gels was injected into the subcutaneous tissue of the rats, and the results of the vascular permeability were assessed after 3 and $6 \mathrm{~h}$. The amount of HP released and $\mathrm{pH}$ of each product was also determined. Data were submitted to statistical test $(\mathrm{p}<0.05)$. Results: At $3 \mathrm{~h}$, the PB showed higher vascular permeability than the other groups. At $6 \mathrm{~h}$, the PB produced similar vascular permeability than WHI, and higher than OPA and CTRL groups. The OPA group had a higher vascular permeability at $6 \mathrm{~h}$ compared to $3 \mathrm{~h}$; there is no difference in other groups. The PB group had higher HP concentrations than the other groups. Conclusion: In general, the PB caused a more considerable amount of inflammatory edema and higher amount of HP released. This results suggesting that these bleaching gels cause greater aggression in soft gingival tissues that eventually ends up in contact with bleaching products.

\section{KEYWORDS}

Tooth bleaching; Carbamide peroxide; Hydrogen peroxide; Capillary permeability.

\section{RESUMO}

Objetivo: A técnica de clareamento domiciliar leva ao contato íntimo do gel clareador com tecidos gengivais, assim, este estudo avaliou a resposta inflamatória imediata, através do teste edemogênico, induzido por gel de clareamento caseiro à base de peróxido de carbamida a $10 \%$ com diferentes agentes dessensibilizantes, a quantificação de peróxido de hidrogênio liberado e o pH dos géis branqueadores. Material e Métodos: Quarenta e oito ratos foram divididos em 4 grupos $(\mathrm{n}=12)$ : grupocontrole CTRL, WP-Whiteness Perfect 10\% (FGM Produtos Odontológicos, Joinville, SC, Brasil), OPA-Opalescence 10\% (Ultradent Products Inc., South Jordan, IT, EUA) e PB-Power Bleaching (BM4, Palhoça, SC, Brasil). Para o teste edemogênico, todos os ratos receberam uma injeção intravenosa de Evan's Blue; após $30 \mathrm{~min}, 0,2 \mathrm{~mL}$ de cada gel clareador foi injetado no tecido subcutâneo dos ratos, e os resultados da permeabilidade vascular foram avaliados após 3 e 6 horas. A quantidade de HP liberada e o $\mathrm{pH}$ de cada produto também foram determinados. Os dados foram submetidos ao teste estatístico $(P<0,05)$. Resultados: Às 3h, o PB apresentou maior permeabilidade vascular que os demais grupos. Às $6 \mathrm{~h}$, o PB produziu permeabilidade vascular semelhante ao WHI e maior que os grupos OPA e CTRL. O grupo OPA apresentou maior permeabilidade vascular às 6 h em relação às 3 h; Não existe essa diferença em outros grupos. O grupo PB apresentou maiores concentrações de HP que os demais grupos. Conclusão: Em geral, o PB causou maior quantidade de edema inflamatório e maior quantidade de HP liberado. Estes resultados sugerem que estes géis branqueadores causam maior agressividade nos tecidos gengivais moles que eventualmente acabam em contato com produtos de branqueamento.

\section{PALAVRAS-CHAVE}

Clareamento dental; Peróxido de carbamida; Peróxido de hidrogênio; Permeabilidade capilar. 


\section{INTRODUCTION}

$\mathrm{T}$ he dental bleaching has been highlighted in esthetic dentistry by delivering impactful results, improving the self-esteem of the patient and their social life [1]. As a proposal for a bleaching treatment, Haywood \& Heymann, in 1989 [2], applied bleaching products of the carbamide peroxide (CP) in acetate trays. This treatment was recognized for being technically simple, biologically safe, and aesthetically effective when truly indicated and performed under the supervision of the professional $[2,3]$..

The CP, when in contact with dental hard tissue, dissociates into urea and hydrogen peroxide (HP) [4], which is the active component responsible for the breakdown of chromogenic agents of the tooth structure [5]. With its low molecular weight, HP penetrates easily through the dental structures, rapidly reaching the pulp tissue [6,7]. It may trigger an inflammatory process [8-10], resulting in different levels of tooth sensitivity [11-13].

To reduce the sensitivity caused by bleaching procedure, some authors reported the use of desensitizing agents in bleaching protocol [12,14-16]. Studies have shown promising results when using potassium nitrate (NP) before or after the HP $[12,15,16]$. It is believed that this desensitizing agent, upon contact with the dentin-pulp complex, modulates the activity of the sodium $(\mathrm{Na}+)$ and potassium $(\mathrm{K}+)$ channels present on the cell membrane, thereby affecting the transmission of nerve impulses and decreasing tooth sensitivity [17].

Another desensitizing agent recently incorporated into bleaching protocol is potassium oxalate (PO). This compound was introduced to Dentistry in the 1970s with the intent of treating dentinal hypersensitivity, inducing precipitation in the exposed dentin tubules, reducing the movement of dentinal fluid, and consequently, the pain [17]. Thus, manufacturers incorporated these desensitizing agents into the bleaching gels to reduce the sensitivity during the bleaching technique, making this a safer procedure.

However, the bleaching gel may stay in direct contact with gingival tissues, and the effects of these desensitizers in the soft tissue have not yet been studied. The contact with gingival tissues occurs mainly in the at-home dental bleaching in which the bleaching gel deposited inside the tray may overflow when the tray is placed intra-orally, remaining in contact with the oral soft tissues and mucous membrane of the gastrointestinal tract $[18,19]$.

The most used methods to evaluate the biocompatibility of bleaching gels are in vitro studies with cell culture [7] and in vivo tests on animals teeth [10] or humans [11]. However, the edemogenic test allows to quantify the level of edema, that shows the immediate response of soft tissues to materials, as the production of edema is proportional to the toxic action of the product [20]. Vascular permeability is a common pathogenic process that is often encountered during the development of inflammation [21], and it is used to assess the irritating potential of dental materials $[20,22]$.

Therefore, this study aimed to evaluate the amount of edema that different bleaching agents cause in the subcutaneous tissue of rats, at different analysis periods. The HP concentration of each product also was evaluated. The null hypotheses were that the different bleaching gels agents would not differ regarding (1) The inflammatory response (regarding edema) in the subcutaneous tissue of rats; (2) The amount of HP released.

\section{MATERIALS AND METHODS}

A total of 48 male Wistar rats (Rattus albinus), weighing between 200-240 g, were used in this study $(n=12)$. The animals were kept in a temperature-controlled environment at $22^{\circ} \mathrm{C} \pm 1^{\circ} \mathrm{C}$ and under a controlled light cycle (12 h light and $12 \mathrm{~h}$ dark), with a solid 
diet and water available ad libitum. The experimental protocol was approved by the Ethics Committee on the Use of Animals of the Araçatuba Dental School, UNESP-Univ Estadual Paulista (CEUA- ${ }^{\circ} 2014-00787$ ) and the study was conducted in accordance with the ARRIVE guidelines [23].

\section{Experimental design}

This article has two studies:

a) In vivo experimental analysis

Factors of analysis

- Bleaching gels in 4 levels (1- Controle, 2- WhitenessPerfect 10\%, 3- Opalescence, 4PowerBleaching)

- Time in 2 levels (3 e 6 hours)

- Response variable - Quantification of edema

b) In vitro experimental analysis:

- Bleaching gels in 4 levels (1- Controle, 2- WhitenessPerfect 10\%, 3- Opalescence, 4PowerBleaching)

- Response variable - The PH degradation rate

Table 1 - Division of groups according to the product evaluated

\begin{tabular}{|c|c|c|c|c|}
\hline $\begin{array}{l}\text { Group } \\
(n=12)\end{array}$ & $\begin{array}{l}\text { Bleaching ac- } \\
\text { tive ingredient }\end{array}$ & Product tested & $\begin{array}{l}\text { Desensitizing } \\
\text { agent }\end{array}$ & pH \\
\hline CTRL & - & Placebo gel & - & 7.00 \\
\hline WH & $\begin{array}{l}10 \% \text { Carbami- } \\
\text { de peroxide }\end{array}$ & $\begin{array}{l}\text { Whiteness } \\
\text { perfect }^{*}\end{array}$ & $\begin{array}{l}\text { Potassium nitrate } \\
\text { and sodium fluoride }\end{array}$ & 5.94 \\
\hline OPA & $\begin{array}{l}10 \% \text { Carbami- } \\
\text { de peroxide }\end{array}$ & $\begin{array}{l}\text { Opalescence } \\
\qquad \mathrm{PF}^{\star \star}\end{array}$ & $\begin{array}{l}\text { Potassium nitrate } \\
\text { and sodium fluoride }\end{array}$ & 6.76 \\
\hline PB & $\begin{array}{l}10 \% \text { Carbami- } \\
\text { de peroxide }\end{array}$ & $\begin{array}{l}\text { Power Blea- } \\
\text { ching }\end{array}$ & $\begin{array}{l}3 \% \text { potassium } \\
\text { oxalate }\end{array}$ & 5.64 \\
\hline
\end{tabular}
edema

Edemogenic test to quantify the level of

The rats were anesthetized by intramuscular injections of ketamine $(80 \mathrm{mg}$ / $\mathrm{kg}$, Ketamina Agener 10\%, União Química Farmacêutica Nacional S/A - Embu-Guaçu, SP, Brasil) and xylazine $(10 \mathrm{mg} / \mathrm{kg}$, Xilazin, Syntec do Brazil LTDA - Cotia, SP, Brasil). Then, the animals received an intravenous injection of $1 \%$ Evan's blue dye (Difco Laboratories, Livonia, MI, USA) diluted in distilled water, at a dosage of $0.2 \mathrm{~mL}$ of solution per $100 \mathrm{~g}$ of body weight, using a $1 \mathrm{~mL}$ insulin syringe, through the penile vein of the animal [20].

After 30 minutes, $0.2 \mathrm{~mL}$ of the bleaching gels was injected with insulin syringe subcutaneously into the dorsum region of each rat, near the tail and using the median line as a reference [20], forming the described groups in Table 1.

After 3 and 6 hours, the animals were killed by an overdose of the anesthetic solution (240mg/Kg, Thiopentax; Cristália Produtos Químicos Farmacêuticos LTDA, Itapira, SP, Brazil), followed by manual trichotomy of the dorsal region to reveal the area of edema, and a $23-\mathrm{mm}$ diameter tissue fragment containing a blue halo in the center was removed [20]. These samples were fixed in $4 \mathrm{~mL}$ of formamide and stored at $37^{\circ} \mathrm{C}$ for $72 \mathrm{~h}$. Then, the samples were filtered, and the solutions were spectrophotometrically analyzed at $630 \mathrm{~nm}$, which is the maximum absorption peak of the dye. Thus, the intensity of the inflammatory edema caused by subcutaneous injection by bleaching gel was determined. 


\section{released}

\section{Quantification of hydrogen peroxide}

For quantification of the HP released, five syringes of each bleaching gel were used. The method used is based on titration using oxidation-reduction reaction with potassium permanganate, which provides the amount of HP released by each bleaching gel [23]. The reaction is according to the following formula: $2 \mathrm{KMnO}_{4}+5 \mathrm{H}_{2} \mathrm{O}_{2}+4 \mathrm{H}_{2} \mathrm{SO}_{4}=2 \mathrm{KHSO}_{4}+$ $2 \mathrm{MnSO}_{4}+5 \mathrm{O}_{2-}+8 \mathrm{H}_{2} \mathrm{O}$.

The potassium permanganate solution (solution 1) was prepared by mixing $0.2 \mathrm{~g}$ of sodium oxalate, $250 \mathrm{~mL}$ of distilled water, and $15 \mathrm{~mL}$ of sulfuric acid at $80^{\circ} \mathrm{C}$ for $30 \mathrm{~min}$ [24]. The solution was kept in an amber glass and protected from light for $24 \mathrm{~h}$.

Two grams of each bleaching gels were weighed on an analytical balance and diluted in $10 \mathrm{~mL}$ of distilled water (solution 2) to determine the amount of HP in a sample. Then, solution 1 was added to solution 2 at a rate of $0.1 \mathrm{~mL} / \mathrm{sec}$, until a violet color was observed. This color change of the solution indicated the equivalence point, i.e., the point at which all HP was consumed. The volume of solution 1 required to change the color of the final solution was applied to the following formula: $\mathrm{C}=\mathrm{V} \times \mathrm{Cf} \times 1.701 \times 100 \mathrm{~m}$, where $(\mathrm{w} / \mathrm{w})$;

$\mathrm{C}=$ concentration of hydrogen peroxide

$\mathrm{V}=$ volume of solution 1 in milliliters added during titration;

$\mathrm{Cf}=$ correction factor for the $0.1 \mathrm{~N}$ potassium permanganate solution;

$\mathrm{m}=$ mass of the sample of the bleaching product in milligrams.

\section{Statistical analysis}

Data were tabulated, and the normality and homogeneity of variance assumptions were verified. The data obtained in the edemogenic test were tabulated and submitted to twoway Analysis of Variance, followed by Tukey's test and the data obtained in the hydrogen peroxide concentration were submitted to oneway Analysis of Variance, followed by Tukey's test, both at a significance level of $5 \%$.

\section{RESULTS}

\section{Edemogenic Test}

The data of edemogenic test can be observed in Table 2. The CTRL group was significantly different to the bleaching gels groups at 3 or $6 \mathrm{~h}$. Regarding the bleaching gel groups, at $3 \mathrm{~h}$, the $\mathrm{PB}$ presented higher edema than $\mathrm{WH}$ and $\mathrm{PB}(\mathrm{p} \leq 0,001)$, rejecting the first null hypothesis. At $6 \mathrm{~h}$, this difference was found when compared to OPA group; there was no significant difference between the WH and OPA groups in this period. The OPA showed a significant increase of the edema at $6 \mathrm{~h}(\mathrm{p}=0,029)$; there was no difference of the edema in 3 or $6 \mathrm{~h}$ from the other groups.

Table 2 - Results of the edemogenic test of bleaching gels

\begin{tabular}{|c|c|c|c|c|c|}
\hline & & CTRL & WH & OPA & PB \\
\hline \multirow{2}{*}{$\begin{array}{l}\text { Edemo- } \\
\text { genic } \\
\text { test }^{*}\end{array}$} & $3 \mathrm{~h}$ & $\begin{array}{c}0.002 \\
( \pm 0.001) \mathrm{Ad}\end{array}$ & $\begin{array}{c}1.440 \\
( \pm 0.112) \mathrm{Ab}\end{array}$ & $\begin{array}{c}1.198 \\
( \pm 0.200) \mathrm{BC}\end{array}$ & $\begin{array}{c}1.778 \\
( \pm 0.118) \mathrm{Aa}\end{array}$ \\
\hline & $6 \mathrm{~h}$ & $\begin{array}{c}0.002 \\
( \pm 0.000) \mathrm{Ac}\end{array}$ & $\begin{array}{c}1.640 \\
( \pm 0.219) \text { Aab }\end{array}$ & $\begin{array}{c}1.488 \\
( \pm 0.197) \mathrm{Ab}\end{array}$ & $\begin{array}{c}1.870 \\
( \pm 0.197) \mathrm{Aa}\end{array}$ \\
\hline
\end{tabular}

\section{Hydrogen peroxide concentration}

The data from the hydrogen peroxide concentration is displayed in Figure 1. When the amount of peroxide released by the bleaching agents was quantified, a statistically significant difference between groups was noted, rejecting the second null hypothesis $(\mathrm{p}<0.001)$. The PB group had a higher hydrogen peroxide concentration compared to other groups. 


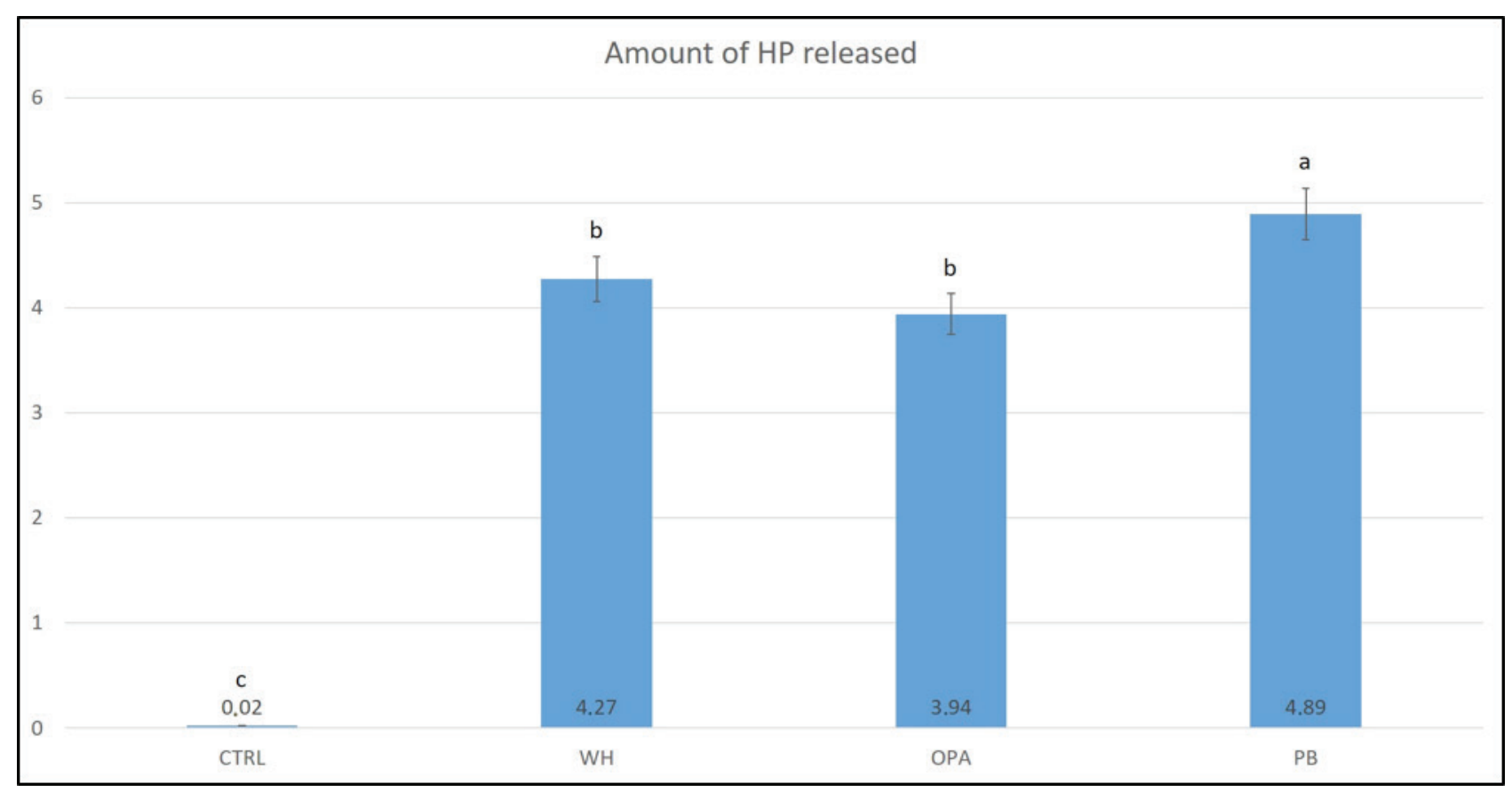

Figure 1 - Results of the quantification of released hydrogen peroxide and $\mathrm{pH}$ analysis of bleaching gels (different letters indicate significant differences between columns).

\section{DISCUSSION}

This study evaluated the biological response from bleaching gels and showed that bleaching gels with different desensitizing agents in its composition presented different vascular permeability in the subcutaneous tissue of rats. Furthermore, bleaching gels with the same concentration of $\mathrm{CP}$ promoted the different amount of HP released.

Most commercially available at-home whitening products produce levels of hydrogen peroxide ranging from $3.5 \%$ to $7.5 \%$, based on carbamide peroxide at concentrations of $10 \%$ to $22 \%[12,24]$. Due to the relatively low concentrations of hydrogen peroxide, the athome technique has been considered safe and effective, when monitored by professionals [25].

However, some side-effects can still be observed, particularly when the gel comes into contact with the soft tissue $[3,26]$. In vivo studies evaluating the degree of gingival inflammation after exposure to the bleaching gels used athome show that between $25 \%$ and $40 \%$ of patients experienced some level of gum irritation during the dental bleaching, and this fact, along with tooth sensitivity, results in more complaints by patients during treatment [27]. In another clinical study, Carlos et al. evaluated home bleaching agents using different types of trays. They observed that all patients submitted to bleaching treatment, regardless of the type of tray, presented significant gingival irritation caused by agents bleaching agents [28]. In an in vitro study, Furukawa et al. evaluated the genotoxic effect of hydrogen peroxide on human gingival fibroblasts. In this study, they used hydrogen peroxide at low concentrations and observed that there is a stimulation of the proinflammatory tumor necrosis factor (TNF) cascade in cytokines in gingival fibroblasts due to contact with the bleaching agents [29].

Based on these clinical observations, this study used methods previously used in endodontics [30] and quantified the vascular permeability caused by direct contact of various bleaching gels to the connective tissue of rats. This analysis is based on determining the optical density of a solution containing the dye that binds to albumin, a protein that is present in large amounts in inflamed areas [31]. Therefore, the higher the optical density of this solution, the greater the inflammation at the site. Thus, the results of this study indicate, indirectly, the 
inflammatory potential of at-home bleaching gels when they come into contact with mucous membranes. Furthermore, the analysis of edema generated by 3 and $6 \mathrm{~h}$ of contact with the products relates, respectively, to the approximate time typically recommended in the daytime and nighttime use options of the tray.

This study showed that all bleaching gels produced vast edema when compared to the control group. Within $3 \mathrm{~h}$, the gel Power Bleaching $₫ 10 \%$ with potassium oxalate resulted in markedly more edema than other groups. It may be related to the high toxicity of potassium oxalate to the skin and mucous membranes [32]. It is rather worrisome since at-home gels often come into contact with the soft tissues, which can result in tissue irritation. Also, differences in formulations that were not analyzed in this study, as well as recent changes in $\mathrm{pH}$ during the presence of the product in tissues may have contributed to the intense and immediate response produced.

The effectiveness of potassium oxalate was initially proven when the product was applied topically to the exposed dentine structure or teeth with hypersensitivity [33]. However, these clinical conditions represent major contraindications for dental bleaching, as they may encourage excessive penetration of peroxides into the tooth pulp complex [34]. Thus, the possible benefits of using an at-home gel containing potassium oxalate should be studied carefully, as they have direct contact only with the tooth enamel, showing results inferior to other at-home bleaching gels.

Nevertheless, the source of discomfort in hypersensitive teeth is a very distinct sensitivity caused by the dental bleaching. Even considering the superior results reported by Bernardon et al. [35], it is difficult to explain how potassium oxalate could help to relieve the sensitivity caused by penetration of peroxide into the pulp tissue. It is known that the painful sensation caused by bleaching treatment is primarily related to an inflammatory process caused by the action of reactive oxygen species in the pulp cells [7-10,36,37], in addition to the occupation of specific nociceptors in this tissue [38]. On the other hand, the tooth hypersensitivity is primarily related to the dynamics of dentinal fluids [39].
Regarding the amount of hydrogen peroxide in each bleaching gel, Goldstein et al. [40] reported that $10 \%$ carbamide peroxidebased products, when in contact with water or saliva, release approximately $3.5 \%$ hydrogen peroxide. Nevertheless, all gels tested in the present study released higher levels of hydrogen peroxide, notable in the G3 group (containing PO), that produced $4.98 \%$ hydrogen peroxide. This concentration results in a faster color change during treatment than obtained with the other products evaluated, but can also cause a more intense tissue response.

Despite the limitations of the experimental model, this study highlights the need for further studies with bleaching gels containing potassium oxalate, since these products may promote a pronounced tissue response, suggesting that these bleaching gels cause greater aggression in soft gingival tissues that eventually ends up in contact with bleaching products. Furthermore, different bleaching gels labeled as having the same concentration of carbamide peroxide can release different amounts of hydrogen peroxide, which should alert clinicians to the care they should take to indicate dental bleaching, regardless the concentration of the gel used.

\section{CONCLUSION}

In conclusion, the bleaching gels that promoted the higher amount of HP release caused higher vascular permeability. Also, the bleaching gels with potassium oxalate are related to a more intense tissue response.

\section{REFERENCES}

1. Martin J, Rivas V, Vildósola P, Moncada L, Oliveira Junior OB, Saad JR, et al. Personality Style in Patients Looking for Tooth Bleaching and Its Correlation with Treatment Satisfaction. Braz Dent J. 2016 Jan-Feb;27(1):60-5.

2. Haywood VB, Heymann HO. Nightguard vital bleaching. Quintessence Int. 1989 Mar;20(3):173-6.

3. Haywood VB, Leonard RH, Dickinson GL. Efficacy of six months of nightguard vital bleaching of tetracycline-stained teeth. J Esthet Dent. 1997;9(1):13-9.

4. Shi XC, Ma H,Zhou JL, LiW. The effect of cold-light-activated bleaching treatment on enamel surfaces in vitro. Int J Oral Sci. 2012 Dec;4(4):208-13.

5. Kwon SR, WertzPW. Review of the Mechanism of Tooth Whitening. JEsthet Restor Dent. 2015 Sep-0ct;27(5):240-57.

6. Briso ALF, Gonçalves RS, Costa FB, Gallinari MO, Cintra LT, Santos PH. 
Demineralization and hydrogen peroxide penetration in teeth with incipient lesions. Braz Dent J. 2015 Mar-Apr;26(2):135-40.

7. Soares DG, Basso FG, Hebling J, de Souza Costa CA. Concentrations of and application protocols for hydrogen peroxide bleaching gels: effects on pulp cell viability and whitening efficacy. J Dent. 2014 Feb;42(2):185-98

8. Costa CA, Riehl H, Kina JF, Sacono NT, Hebling J. Human pulp responses to in-office tooth bleaching. Oral Surg Oral Med Oral Pathol Oral Radiol Endod. $2010 \mathrm{Apr} ; 109(4): \mathrm{e} 59-64$.

9. Cintra LT, Benetti F, Ferreira LL, Rahal V, Ervolino E, Jacinto Rde C, et al Evaluation of an experimental rat model for comparative studies of bleaching agents. J Appl Oral Sci. 2016 Apr;24(2):171-80.

10. Cintra LT BenettiF Ferreira L Gomes-Filho JE Ervolino E Gallinari M0 et al Penetration capacity, color alteration and biological response of two in-office bleaching protocols. Braz Dent J. 2016 Mar-Apr;27(2):169-75.

11. Rahal V, Gallinari MO, Martins-Junior RL, dos Santos PH, Cintra LTA, Briso ALF. Influence of skin cold sensation threshold in the occurrence of dental sensitivity during dental bleaching: a placebo controlled clinical trial. J Appl Oral Sci. 2018 Jan 18;26:e20170043.

12. Rahal V, Gallinari MO, Perdigão J, Cintra LT, dos Santos PH, Briso AL Quantitative sensory testing of the effect of desensitizing treatment after dental bleaching. Acta Odontol Latinoam. 2015 Dec;28(3):263-70.

13. de Almeida LC, Costa CA, Riehl H, dos Santos PH, Sundfeld RH, Briso Al. Occurrence of sensitivity during at-home and in-office tooth bleaching therapies with or without use of light sources. Acta Odontol Latinoam. 2012;25(1):3-8.

14. Lima AF, Marques MR, Soares DG, Hebling J, Marchi GM, de Souza Costa CA Antioxidant therapy enhances pulpal healing in bleached teeth. Restor Dent Endod. 2016 Feb;:41(1):44-54.

15. Bonafé E, Loguercio AD, Reis A, Kossatz S. Effectiveness of a desensitizing agent before in-office tooth bleaching in restored teeth. Clin Oral Investig. $2014 \mathrm{Apr} ; 18(3): 839-45$.

16. Palé M, Mayoral JR, Llopis J, Vallès M, Basilio J, Roig M. Evaluation of the effectiveness of an in-office bleaching system and the effect of potassium nitrate as a desensitizing agent. Odontology. 2014 Jul;102(2):203-10.

17. Pereira R, Chava VK. Effects of a potassium nitrate mouthwash on dentinal tubules--a SEM analysis using the dentine disc model. J Int Acad Periodontol. 2002 Apr;4(2):44-8.

18. Li Y. Toxicological considerations of tooth bleaching using peroxidecontaining agents. J Am Dent Assoc. 1997 Apr;128 Suppl:31S-36S.

19. de Geus JL, Rezende M, Margraf LS, Bortoluzzi MC, FernándezE, Loguercio $A D$, et al. Evaluation of genotoxicity and efficacy of at-home bleaching in smokers: a single-blind controlled clinical trial. Oper Dent. 2015 MarApr;40(2):E47-55.

20. Machado AC, Dezan Junior E, Gomes-Filho JE, Cintra LT, Ruviére DB, Zoccal $\mathrm{R}$, et al. Evaluation of tissue reaction to Aroeira (Myracrodruon urundeuva) extracts: a histologic and edemogenic study. J Appl Oral Sci. 2012 JulAug;20(4):414-8.

21. Kunstfeld R, Hirakawa S, Hong YK, Schacht V, Lange-Asschenfeldt B Velasco $P$,et al. Induction of cutaneous delayed-type hypersensitivity reactions in VEGF-A transgenic mice results in chronic skin inflammation associated with persistent lymphatic hyperplasia. Blood. 2004 Aug 15;104(4):1048-57.

22. Guimarães SA, Akatsu T, Tago EM, Consolaro A. Assessment of the antiexudative and antiproliferative activities of non-steroidal antiinflammatory drugs in inflammatory models developed in rats by subcutaneous implantation of bacterial cell walls from the dental plaque. Inflammation. 1996 Dec;20(6):623-36.

23. Kilkenny C, Browne WJ, Cuthill IC, Emerson M, Altman DG. Anima research: reporting in vivo experiments: ARRIVE guidelines. PLOSBiol. 2010;8(6):e1000412

24. Marson FC, Gonçalves RS, Silva CO, Cintra LT, Pascotto RC, Santos PH, et al. Penetration of hydrogen peroxide and degradation rate of different bleaching products. Oper Dent. 2015 Jan-Feb;40(1):72-9.

25. Boushell LW, Ritter AV, Garland GE, Tiwana KK, Smith LR, Broome A, et al. Nightguard vital bleaching: side effects and patient satisfaction 10 to 17 years post-treatment. J Esthet Restor Dent. 2012 Jun;24(3):211-9.

26. Powell L V Bales DJ. Tooth bleaching: its effect on oral tissues. J Am Dent Assoc. 1991Nov;122(11):50-4.

27. Kirsten GA, Freire A, de Lima AA, Ignácio SA, Souza EM. Effect of reservoirs on gingival inflammation after home dental bleaching. Quintessence Int. 2009 Mar;40(3):195-202

28. Carlos NR, Bridi EC, Amaral F, França F, Turssi CP, Basting RT. Efficacy of home-use bleaching agents delivered in customized or prefilled disposable trays: a randomized clinical trial. Oper Dent. 2017 Jan/Feb;42(1):30-40

29. Furukawa M, K-Kaneyama JR, Yamada M, Senda A, Manabe A, Miyazaki A. Cytotoxic effects of hydrogen peroxide on human gingival fibroblasts in vitro. Oper Dent. 2015 Jul-Aug;40(4):430-9.

30. Rutberg M, Spangberg E, Spangberg L. Evaluation of enhanced vascular permeability of endodontic medicaments in vivo. JEndod. 1977 Sep;3(9):347-51.

31. Udaka K, Takeuchi Y,Movat HZ Simple method for quantification oh enhanced vascular permeability. Proc Soc Exp Biol Med. 1970 Apr;133(4):1384-7.

32. Guo C, McMartin KE. The cytotoxicity of oxalate, metabolite of ethylene glycol, is due to calcium oxalate monohydrate formation. Toxicology. 2005 Mar 30;208(3):347-55

33. Mantzourani M, Sharma D. Dentine sensitivity: past, present and future. $J$ Dent. 2013 Jul;41Suppl 4:S3-17.

34. Markowitz K. Pretty painful: why does tooth bleaching hurt? Med Hypotheses. 2010 May;74(5):835-40.

35. Bernardon JK Vieira Martins M, Branco Rauber G, Monteiro Junior S Baratieri LN. Clinical evaluation of different desensitizing agents in homebleaching gels. J Prosthet Dent. 2016 Jun;115(6):692-6

36. de Almeida LC, Soares DG, Azevedo FA, Gallinari MO, Costa CA, dos Santos $\mathrm{PH}$, et al. At At-Home Bleaching: Color Alteration, Hydrogen Peroxide Diffusion and Cytotoxicity. Braz Dent J. 2015 Jul-Aug;26(4):378-83

37. de Oliveira Duque CC, Soares DG, Basso FG, Hebling J, de Souza Costa CA. Influence of enamel/dentin thickness on the toxic and esthetic effects of experimental in-office bleaching protocols. Clin Oral Investig. 2017 Nov:21(8):2509-20

38. Caviedes-Bucheli J, Ariza-García G, Restrepo-Méndez S, Ríos-Osorio N, Lombana N, Muñoz HR. The Effect of tooth bleaching on substance $P$ expression in human dental pulp. J Endod. 2008 Dec;34(12):1462-5

39. Pashley DH. Dentin: a dynamic substrate--a review. Scanning Microsc. 1989 Mar;3(1):161-74

40. Goldstein GR, Kiremidjian-Schumacher L. Bleaching: is it safe and effective? JProsthet Dent. 1993 Mar;69(3):325-8

\section{André Luiz Fraga Briso} (Corresponding address)

Department of Restorative Dentistry,

Rua José Bonifácio, 1193, Vila Mendonça. Araçatuba-SP, Brazil.

CEP: 16015050.

Tel: +55 $183636-3348$

Date submitted: 2017 Dec 20

Email: alfbriso@foa.unesp.br 